\title{
Changes in Cytoskeletal Proteins in the Rat Facial Nucleus Following Axotomy
}

\author{
Wolfram Tetzlaff, Mark A. Bisby, and Georg W. Kreutzberg ${ }^{1}$ \\ Department of Medical Physiology, University of Calgary, Calgary, Alberta T2N 4N1, Canada and 'Department of \\ Neuromorphology, Max-Planck-Institute for Psychiatry, D-8033 Martinsried-Planegg, Federal Republic of Germany
}

\begin{abstract}
Changes in L-35S-methionine incorporation into cytoskeletal proteins of the facial nucleus of the rat were studied at various times after unilateral crush or resection of the facial nerve by using 2-dimensional gel electrophoresis and fluorography. We found an increase in labeling of actin and tubulin and a decrease in the $68 \mathrm{kDa}$ and $150 \mathrm{kDa}$ neurofilament polypeptides (200 kDa was not studied). The increase in actin and decrease in neurofilament polypeptide labeling was already significant by $24 \mathrm{hr}$ after nerve resection. These changes were more pronounced after nerve resection than after nerve crush on day 7; actin labeling increased to $270 \%$, and tubulin to $205 \%$ of contralateral normal nuclei after resection, whereas both proteins increased to only $165 \%$ after crush. Neurofilament labeling decreased to $28 \%$ of the contralateral side after resection and to $50 \%$ after crush. Immunocytochemistry with a monoclonal antibody to the 150 kDa neurofilament component revealed decreased immunoreactivity in the axotomized facial axons at the inner facial genu, $1 \mathrm{~cm}$ proximal to the crush. In contrast, neurofilament immunoreactivity was not decreased in the axotomized perikarya of the facial motoneurons. All changes returned to normal 3 weeks after crush. When axonal regeneration was impeded by nerve resection, incorporation into tubulin remained elevated and into neurofilament proteins remained depressed. Actin returned to normal after either nerve resection or crush.

We conclude that the synthesis of tubulin and neurofilament proteins following axotomy is regulated by successful axonal regeneration and/or target contact. Actin synthesis seems to be regulated independently of target-derived factors.
\end{abstract}

Axotomy of peripheral neurons induces a variety of morphological and biochemical changes in the neuronal cell bodies known as chromatolysis or the retrograde reaction (for review, see Lieberman, 1971; Grafstein and McQuarrie, 1978; Kreutzberg, 1982; Tetzlaff et al., 1986b). This retrograde cell body reaction reflects changes in RNA metabolism (Edström, 1959; Watson,

\footnotetext{
Received May 22, 1987; revised Jan. 7, 1988; accepted Feb. 8, 1988.

This work was supported by a grant from the Medical Research Council of Canada to M. A. Bisby (MT 5198). W. Tetzlaff is the recipient of a post-doctoral fellowship from the Alberta Heritage Foundation for Medical Research. Thanks are due to A. Ertlmaier for technical assistance and to Drs. I. M. Parhad and T. A. Reh for critical reading of the manuscript.

Correspondence should be addressed to Dr. W. Tetzlaff, Department of Medical Physiology, University of Calgary, 3330 Hospital Drive N.W., Calgary, Alberta T2N 4N1, Canada.

Copyright (C) 1988 Society for Neuroscience $0270-6474 / 88 / 093190-10 \$ 02.00 / 0$
}

1968; Aldskogius et al., 1980; for review, see Austin, 1985), which in turn induce changes in protein synthesis (Brattgård et al., 1958; for review, see Grafstein and McQuarric, 1978). It is thought that at least a portion of these changes involves cytoskeletal proteins needed for the regeneration of a new axon, i.e., actin, tubulin, and neurofilament proteins. The importance of these cytoskeletal proteins in regeneration is supported by the finding that there is a close correlation between the $\mathrm{SCb}$ axonal transport rate of actin and tubulin and the rate of axonal elongation in regenerating rat nerves (McQuarrie, 1983; Wujek and Lasek, 1983). Lasek and Katz (1987) proposed that axonal elongation is achieved by an elongation of the axonal cytoskeleton which is synthesized and assembled at the cell body and which then moves down the axon either as a continuous network or as individual polymers (Lasek, 1986; but see also Bamburg et al., 1986; Nixon and Logvinenko, 1986).

Although the mechanisms of slow axonal transport, as well as the transport forms of the cytoskeletal proteins, are not known, changes in their rates of synthesis at the cell body may play an important role in axonal regeneration. However, little is known about the magnitude and time course of changes in cytoskeletal protein synthesis during the various stages of axon regeneration, such as initial sprouting, elongation, and maturation.

In the present study we analyzed changes in cytoskeletal proteins in the motor nucleus of the rat facial nerve during various stages of regeneration. Specifically, we investigated whether the synthesis of cytoskeletal proteins was regulated by successful regeneration of the axon. We therefore compared synthesis after nerve crush, which permits axonal regeneration, with synthesis after nerve resection, which impedes regeneration. Preliminary data have been published in abstract form (Tetzlaff et al., 1986a).

\section{Materials and Methods}

Animals. Male Sprague-Dawley rats (230-300 gm) were kept in a $14 \mathrm{hr}$ light: $10 \mathrm{hr}$ dark cycle and fed a standard diet and water ad libitum.

Surgery. Rats were anesthetized with sodium pentobarbital $(32 \mathrm{mg} /$ $\mathrm{kg}$ ) plus chloral hydrate $(150 \mathrm{mg} / \mathrm{kg})$, and the left facial nerve was exposed at the stylomastoid foramen. In 40 rats, the nerve was crushed twice with a pair of Dumont \#5 forceps for $30 \mathrm{sec}, 2-3 \mathrm{~mm}$ from the stylomastoid foramen (about $12 \mathrm{~mm}$ distal to the motoneurons in the brain stem). In selected animals, immunocytochemical staining for neurofilaments was used $2 \mathrm{~d}$ after lesioning to verify that the nerves were completely crushed. In another 34 rats, the nerve was transected 2-3 $\mathrm{mm}$ distal from the stylomastoid foramen and a $1 \mathrm{~cm}$ segment excised in order to impede regeneration.

To prepare the rats for a stereotaxic injection of $\mathrm{L}-{ }^{35} \mathrm{~S}-\mathrm{methionine}$ into the brain stem, a 12 gauge guide cannula $4 \mathrm{~mm}$ long was stereotaxically implanted $2 \mathrm{~mm}$ caudal to sigma in the midline (Kopf Instruments stereotaxic apparatus; incisor bar at $-3.5 \mathrm{~mm}$ ). At various time intervals 
after axotomy/needle implantation the rats were lightly ancsthetized with ether and $100 \mu \mathrm{Ci} / 5 \mu \mathrm{l}$ of $\mathrm{L}^{-35} \mathrm{~S}$-methionine (Amersham; specific activity $>1000 \mathrm{Ci} / \mathrm{mmol}$ ) was injected using 30 gauge needle attached to a microliter syringe (Hamilton). This penetrated no deeper than 8 $\mathrm{mm}$ into the brain stem. The rais were killed $2 \mathrm{hr}$ after injection, and the brain stems were frozen on dry ice. The facial nuclei were isolated by microdissection and stored at $-70^{\circ} \mathrm{C}$. ' I wo facial nuclei (4000-5000 motoneurons/nucleus) were pooled for each analysis. Five microliters of each sample were precipitated with $10 \%$ trichloroacetic acid, dissolved in Protosol (NEN-Dupont), and counted to estimate the total protein-bound activity in each sample. To compare changes in cytoskeletal protein synthesis between right (control) and left (axotomized) facial nuclei, equal cpms of protein-bound radioactivity of right and left samples were loaded on the gels.

To take into account changes in overall $\mathrm{L}^{-35} \mathrm{~S}$-methionine incorporation (cpm/mg protein) due to axotomy, and to correct for variations in the isotope application, normalization experiments were carried out (see below).

Two-dimensional SDS-PAGE. The procedure of O'Farrell (1975) was used for 2-dimensional gel electrophoresis, with the following modifications. For isoelectric focusing, an Ampholyte (LKB) mixture of $\mathrm{pH}$ $4-6$, pH 6-8, and $\mathrm{pH} 3-10$ in a ratio of $4: 4: 1$ was used. The SDSpolyacrylamide gels contained a linear $5-15 \%$ polyacrylamide gradient (chemicals from BioRad), and in the equilibration buffer for this second dimension we substituted a dithiothreitol (Sigma) solution $(10 \mathrm{mg} / \mathrm{ml})$ for beta-mercaptoethanol. The gels were fixed in a solution of $7 \%$ acetic acid, $50 \%$ methanol in water and stained in Coomassie blue $\mathbf{R}$ prior to DMSO/PPO (dimethylsulfoxide/diphenyloxazole) treatment for fluorography (Bonner and Laskey, 1974). The dried gels were exposed to a preflashed Kodak XAR5 film for $1-8$ weeks at $-70^{\circ} \mathrm{C}$. The fluorographs were analyzed by quantitative densitometry using a video camera connected to an Apple IIe microcomputer (Mariash et al., 1982).

Normalization procedure. To correct for unequal application of $\mathrm{L}-{ }^{35} \mathrm{~S}$ methionine to the 2 nuclei, gels were loaded with the same amount of protein-bound (trichloroacetic acid insoluble) counts. However, this does not take into account incorporation changes (cpm/protein) that might occur due to axotomy and should be included in our calculation. To correct for these changes we exposed both nuclei to the same concentration of labeled precursor by injecting the label into the tail vein or into the lateral ventricle. Experiments without axotomy revealed the same incorporation (cpm/ $/ \mu$ protein) in both facial nuclei. At various times after facial nerve axotomy there were some differences in specific incorporation. 2D-SDS-PAGE of facial nuclei from these experiments where gels were loaded with equal amounts of protein (determined by Bio-Rad protein assay of small volumes of the samples) revealed a group of proteins whose labeling changed by less than $10 \%$ due to axutomy. This group was used as a reference to normalize the data and express incorporation of total label into the proteins of the axotomized side as a percentage of the contralateral (normal) side according to the following formula:

$$
\% \text { change }=\mathrm{cpmP}_{\mathrm{axol}} / \mathrm{cpmP}_{\mathrm{norm}} \times \mathrm{cpmRef}_{\text {norm }} / \mathrm{cpmRef}_{\mathrm{axot}} \times 100,
$$

where $\mathrm{CpmP}$ axot and $\mathrm{cpmP}_{\text {norm }}$ stand for the $\mathrm{cpm}$ in the proteins of interest on the axotomized and normal side, and cpmRef stands for the cpm in the reference proteins of the same fluorographs from the normal and axotomized side. The significance of the percentage changes was tested with a nonparametric Wilcoxon signed-rank test (1-tailed). Despite the fact that percentage changes are nonparametric data, the means and SEM are also shown (in Fig. 2) to provide an idea of the distribution of the data. The percentage changes of different experimental groups (e.g., crush vs. resection) or of different proteins (actin vs. tubulin) were compared with a 2-tailed Wilcoxon-Mann-Whitney test (also known as Wilcoxon's 2 sample rank test).

These normalization experiments were based on an equivalent amount of protein from the right and the left facial nuclei loaded on the gels. The amounts of protein in our isolated facial nuclei were not different in the axotomized and control sides. Normalization according to a group of proteins that showed the same labeling in the fluorographs was therefore justified. However, since the facial nucleus shrinks after axotomy (by $7 \%, 7 \mathrm{~d}$ after cut and by $25 \%$ by $28 \mathrm{~d}$; Tetzlaff and Kreutzberg, 1984) and the biopsy needle used for isolation of the nuclei was always the same, more surrounding tissue is included in our isolated nuclei at later postaxotomy stages. This tissue contains glial cells, axons, and myelin but few neurons. Loading equal $\mathrm{cpm} / \mathrm{mg}$ protein from axotomized and normal sides would result in an underestimation of specific motor nucleus incorporation in the axotomized side due to a greater contribution of protein from the surrounding tissue. For this reason the normalization experiments were performed on days 1,3 , and 7 only when the neuropil shrinkage was minimal $(<7 \%)$. Labeling of proteins after intraveneous or intraventricular injections was much lower than after injection between the facial nuclei; thus, much longer exposures were necessary to obtain satisfactory fluorographs. Direct application was therefore considered the only possible way to obtain a time series of the changes in synthesis following axotomy.

As the normalization procedure represents a manipulation of the data with an inherent error of $\pm 10 \%$, the changes in protein incorporation were also expressed as the ratio of incorporation into 2 proteins within the same fluorograph. This method is insensitive to differences in specific incorporation or technical variations such as injection placement or loading of the gcls. The ratios of the operated side were compared with the ratios on the contralateral control side with a Wilcoxon signedrank test (paired samples, l-tailed). The ratios of different experimental groups were compared with a 2-tailed Wilcoxon-Mann-Whitney test.

We are aware that there may be a loss of some proteins from the facial nuclei by axonal transport during the $2 \mathrm{hr}$ postinjection period. This would apply mainly to the fast transported proteins $(420 \mathrm{~mm} / \mathrm{d})$ and possibly to a minimal extent to the proteins of $\mathrm{SCb}(3-5 \mathrm{~mm} / \mathrm{d})$ of slow axonal transport such as actin and tubulin but probably not to the neurofilament proteins which travel even slower in $\mathrm{SCa}(1 \mathrm{~mm} / \mathrm{d})$ of slow axonal transport. This could lead to underestimation of actin and tubulin relative to neurofilament polypeptides. Thus, the postaxotomy increase in the tubulin/neurofilament ratio and actin/neurofilament ratio might be even higher than reported here.

Immunocytochemistry. Cryostat scctions of the facial nerve and the brain stem were cut at $15 \mu \mathrm{m}$ thickness, thaw-mounted on slides, and fixed with $4 \%$ paraformaldehyde in $0.1 \mathrm{~m}$ phosphate buffer, $\mathrm{pH} 7.4$, for $20 \mathrm{~min}$. The sections were rinsed 4 times in $0.02 \mathrm{M}$ PBS $(0.7 \%)$ and incubated for $1 \mathrm{hr}$ with monoclonal antibodies to neurofilament 68 and neurofilament $160(=150)$ (Boehringer-Mannheim). The antibodies were used in 1:20-1:50 dilution and after several rinses in PBS visualized by an anti-mouse Fab2-fragment coupled to fluorescein (DAKOPATTS, Denmark). Controls were processed either without a primary antibody or with mouse $\operatorname{IgG}(20 \mu \mathrm{g} / \mathrm{ml})$ instead of a primary antibody.

\section{Results}

$\mathbf{L}^{-35}$ S-methionine incorporation into the cytoskeletal proteins actin, alpha- and beta-tubulins, and neurofilament proteins was measured at various time points after facial nerve crush and after facial nerve resection. After nerve crush there is rapid regeneration so that the axons reach their target muscles within $14 \mathrm{~d}$, as determined by recovery of movement of the whiskers (Tetzlaff and Kreutzberg, 1984). After a $1 \mathrm{~cm}$ resection, little if any functional recovery occurs within the first 3 months and a neuroma is formed at the end of the proximal stump (unpublished observations). A typical pair of fluorographs from axotomized and normal facial nuclei at $7 \mathrm{~d}$ after crush is shown in Figure 1. The decreased label in neurofilament proteins NF68, NF150, and NF200 is clearly visible, as is the increase in actin label. The increased tubulin label is less obvious due to relative overexposure. In addition, increased label in a $50 \mathrm{kDa}$ polypeptide is apparent: we have identified this as glial fibrillary acidic protein (GFAP) in a separate study (Tetzlaff et al., 1988; see also Graeber and Kreutzberg, 1986).

\section{Ratios of incorporation}

The ratios of $\mathrm{L}^{-35} \mathrm{~S}$-methionine incorporation into the different cytoskcletal proteins of the facial nucleus are given in Table 1. The nonoperated (normal) ratio is compared to the ratio of the operated side. The tubulin/actin ratio was significantly decreased $(p<0.05)$ in axotomized nuclei 1 and $7 \mathrm{~d}$ after resection and $3 \mathrm{~d}$ after crush. In contrast, the ratios tubulin/neurofilament 68 (NF68) and tubulin/neurofilaments 150 (NF150), as well as actin/NF68, turned out to be very sensitive parameters for the 


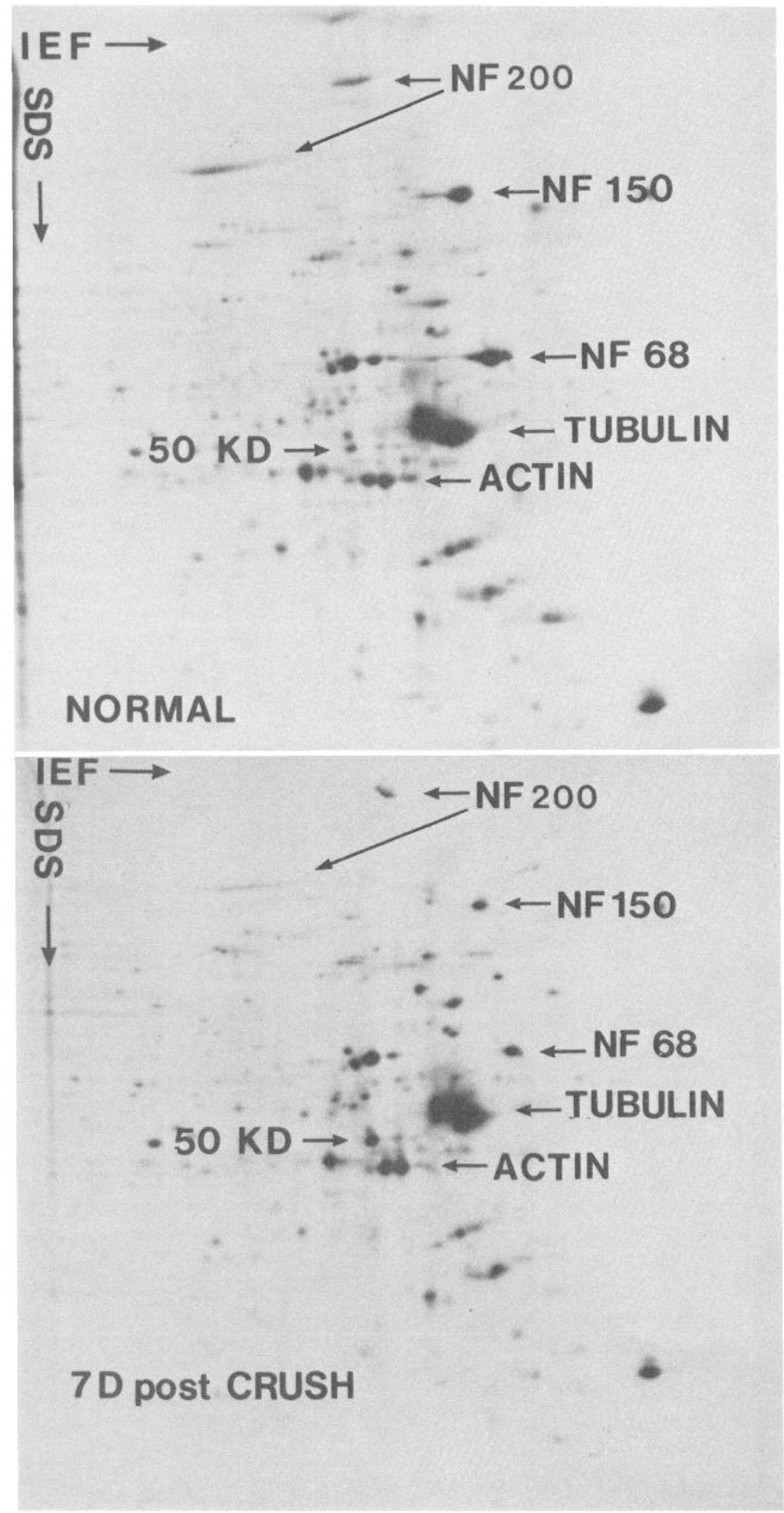

Figure 1. Fluorographs of 2D-PAGE of ${ }^{35} \mathrm{~S}$-methionine-labeled proteins of the normal facial nucleus (top) and $7 \mathrm{~d}$ after crush (bottom). The acidic end of isoelectric focusing gel is to the right. The major cytoskeletal proteins actin, tubulin, NF68, NF150, and NF200 are marked. Note the decreased label in all 3 neurofilament proteins and the increased label in actin and tubulin. The $50 \mathrm{kDa}$ polypeptide is glial fibrillary acidic protein. Fluorographs for densitometric quantification were exposed for shorter time periods, in order to avoid saturation of the film.

relative changes in cytoskeletal protein that occurred after axotomy since these ratios rose as early as $12 \mathrm{hr}$ after axotomy, and by the first day after resection, the ratios tubulin/NF68 and actin/NF68 were significantly increased. These changes in ratio were more pronounced $7 \mathrm{~d}$ after resection than $7 \mathrm{~d}$ after crush ( $p<0.05$, nonparametric Wilcoxon-Mann-Whitney test). By $14 \mathrm{~d}$ after crush these ratios decreased to about twice normal values and were normal by $21 \mathrm{~d}$ after nerve crush. This decrease 

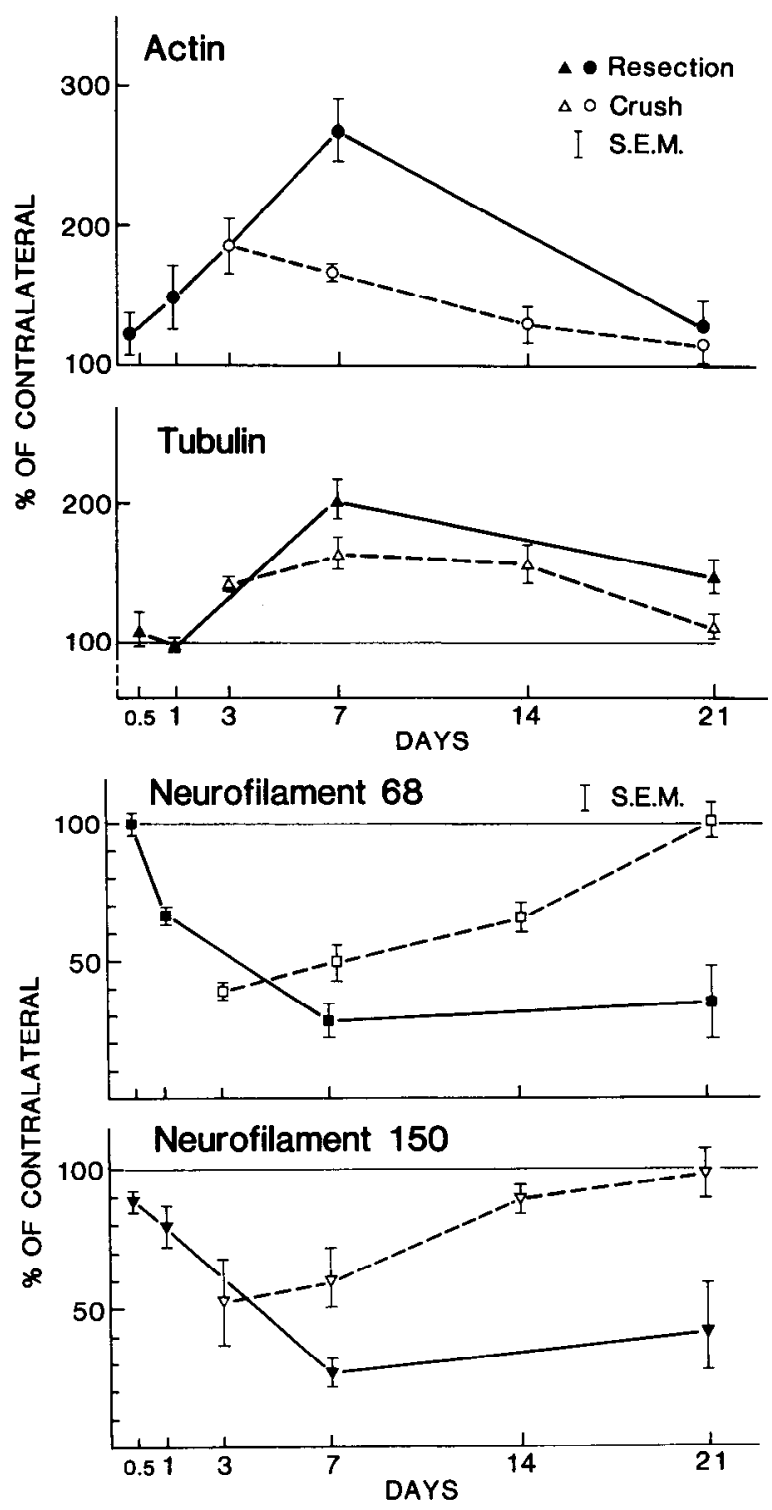

Figure 2. Changes in $\mathrm{L}^{-35} \mathrm{~S}$-methionine incorporation into cytoskeletal proteins of the facial nucleus of the rat after axotomy. The data are expressed as percentages of the contralateral (normal) facial nucleus and are normalized to correct for unequal application of the radiolabeled amino acids to the right and the left facial nuclei (see Materials and Methods). Means \pm SEM are shown, 4-6 observations for each point. Nuclei from 2 animals were pooled for each determination.

was not observed when the nerve had been resected; all 3 ratios were still significantly higher than normal. The neurofilament ratios NF68/NF150 were lower than control $14 \mathrm{~d}(p<0.05)$ after crush, but no changes in this ratio were observed after resection.

\section{Changes in overall incorporation and normalized changes in individual proteins}

To evaluate absolute changes in cytoskeletal protein synthesis we normalized the data as described in Materials and Methods. The overall $\mathrm{L}^{-35} \mathrm{~S}$-methionine incorporations (cpm/ $\mu \mathrm{g}$ proteins) after intravenous or intraventricular injection were slightly less in the axotomized nuclei than in the normal nuclei $1 \mathrm{~d}$ after resection $(94.7+6.4 \%$, mean $\pm \mathrm{SEM}, n=5$, not significant) but were increased to $148.1 \pm 10.1 \%(n=3)$ of normal $7 \mathrm{~d}$ after nerve resection, while $3 \mathrm{~d}$ after crush they were $98.5 \pm 7.5 \%(n$ $=4)$ and $117 \pm 7.3 \%(n=7)$ of normal after $7 \mathrm{~d}$. When equal amounts $(\mu \mathrm{g})$ of protein were loaded on 2-dimensional gels, the fluorographs of these experiments revealed a group of proteins whose labeling changed by less than $+10 \%$ in response to axotomy. This group (MW 75-100, pI 5.2-5.6) was taken as a reference group for normalization of the data, as described above.

Actin

Incorporation of $\mathbf{L}^{-35} \mathrm{~S}$-methionine into actin was increased 24 hr after resection (149\%) (Fig. 2). A further increase occurred by $7 \mathrm{~d}(270 \%)$, and this was followed by a decrease to the normal range by $21 \mathrm{~d}$ after resection. After crush the incorporation of label into actin was less $(p<0.05)$ than after resection $7 \mathrm{~d}$ postaxotomy (166 vs. $270 \%$ ). It decreased to $130 \%$ of normal $14 \mathrm{~d}$ postcrush, reaching the normal range by $21 \mathrm{~d}$.

\section{Tubulin}

Total tubulin activity was pooled, since alpha- and beta-tubulin did not always resolve into 2 clearly defined spots on the $2 \mathrm{D}$ gels. There was no significant change in $\mathrm{L}^{35} \mathrm{~S}-$ methionine incorporation into tubulin $24 \mathrm{hr}$ after nerve resection (Fig. 2). Seven days after resection, tubulin labeling was $205 \%$ of normal, and by $21 \mathrm{~d}$, it still remained higher than normal (149\%). In the regenerating nerve after crush, tubulin label was $132 \%$ of normal at $3 \mathrm{~d}$. This increase in tubulin labeling was sustained at $7(163 \%)$ and $14 \mathrm{~d}(156 \%)$ but subsided to normal range $(112 \%)$ by $21 \mathrm{~d}$.

\section{Neurofilament proteins}

The 68 and $150 \mathrm{kDa}$ (NF68 and NF150) neurofilament polypeptides were revealed as sharply circumscribed spots on 2D gels. The $200 \mathrm{kDa}$ polypeptide appeared as an S-shaped smear, presumably due to variable phosphorylation (Julien and $\mathrm{Mu}$ shynski, 1982; Black et al., 1986) and could not be included in this analysis. The identities of these spots were confirmed by immunoblotting using monoclonal antibodies (BoehringerMannheim) to each of these polypeptides (data not shown).

A decrease in NF 150 labeling was observed as early as 12 hr postaxotomy ( $86 \%$ of normal), and by $24 \mathrm{hr}$ after resection both NF68 and NF150 were significantly reduced (68 and 78\%). At $7 \mathrm{~d}$ after resection, labeling was further reduced (29 and 28\%), and $21 \mathrm{~d}$ after resection, labeling was still profoundly decreased ( 35 and $42 \%$ ). After nerve crush, when regeneration occurred, the minimum measured depression occurred at $3 \mathrm{~d}$ (NF68, 39\%; NF150, 53\%). Seven days after crush, values were significantly higher than after resection (NF68, 49 vs. 29\%; NF150, 59 vs. $28 \%$ ), and $14 \mathrm{~d}$ after crush levels had recovered to 66 and $89 \%$ of control. After $21 \mathrm{~d}$, control values were restored (102 and $98 \%$ ).

The possibility that the findings $21 \mathrm{~d}$ after resection were due to neuronal cell death was ruled out by examinatin of cresyl violet-stained serial sections. Cell death was not evident at 21 $\mathrm{d}$ and after 3 months neuronal loss was only $20 \%$ (unpublished observations).

\section{Neurofilament immunocytochemistry}

Immunocytochemistry using monoclonal antibodies against each of the neurofilament proteins revealed a dramatic decrease in immunoreactive material in the proximal axons at the inner facial genu at $7 \mathrm{~d}$ after crush (Fig. 3, $a$ and $b$ ). This was even more pronounced after resection of the facial nerve (Fig. 3, $e$ 
and $f$ ). Here, at the inner facial genu, the axons were cut perpendicular to their course $1.5-2.5 \mathrm{~mm}$ from the cell bodies (i.e., more than $10 \mathrm{~mm}$ proximal to the site of axotomy). The shrinkage of their caliber, as well as the shrinkage of the entire inner facial genu, was evident (Fig. 3, $a, b, e$, and $f$; see also Kreutzberg and Schubert, 1971). Immunostaining of the facial nuclei revealed no obvious changes in the perikarya of the axotomized motoneurons (Fig. 3, $c, d, g$, and $h$ ), despite the decrease in $\mathrm{L}^{35} \mathrm{~S}$-methionine incorporation into the neurofilament proteins. In contrast, the neuropil between the axotomized facial motoneurons displayed less neurofilament immunoreactive material.

\section{Discussion}

This study evaluated changes in $\mathrm{L}^{-35} \mathrm{~S}$-methionine incorporation into cytoskeletal proteins in the facial nucleus of the rat at various times after crush or resection of the facial nerve. Our results show increased incorporation into actin and tubulin and decreased incorporation into the neurofilament proteins. These changes were more pronounced after resection when regeneration was prevented than after crush when regeneration occurred. They returned to normal by 3 weeks after crush, 1 week after the axons had arrived at the peripheral targets. However, when regeneration was prevented by nerve resection, tubulin labeling was still increased and neurofilament NF68 and NF150 labeling was still depressed after 3 weeks. Actin labeling decreased to normal whether or not regeneration occurred. Results from in situ hybridization studies with specific cDNAs to tubulin and actin demonstrated that these changes are mainly $(>90 \%)$ neuronal rather than glial (Tetzlaff et al., 1987) and support the view that the incorporation changes reflect changes in synthesis rate.

\section{Overall protein synthesis}

Earlier studies on changes in overall protein synthesis following axotomy have given variable results (Brattgård et al., 1958; Engh et al., 1971; McLoon and LaVelle, 1981; Aldskogius et al., 1984; Smith et al., 1984; Singer and Mehler, 1986). In light of the present findings this is not surprising. Different overall changes would be expected with different types of lesions (resection vs. crush; see also Singer and Mehler, 1986). Moreover, in different neuronal types the relative proportions of the cytoskeletal proteins, which account for a major part of the total protein synthesis, are different. For example, after axotomy large neurons in the dorsal root ganglia showed a more pronounced drop in neurofilament 68 mRNA than small neurons (Hoffman et al., 1987).

\section{Time course of cytoskeletal protein synthesis}

Various neuronal systems have shown an increased tubulin synthesis following axotomy, such as the fish visual system (Heacock and Agranoff, 1976; Burrell et al., 1979; Giulian et al., 1980; Neumann et al., 1983), frog motoneurons (Sinicropi and McIlwain, 1983), frog and mammalian dorsal root ganglia, and mammalian superior cervial ganglia (Hall et al., 1978; Hall, 1982; Quesada et al., 1986). For the latter, an increase in actin synthesis has been reported as well (Hall et al., 1978; Hall, 1982). Wc have extended these findings to regenerating mammalian motoneurons and show that tubulin and actin are differentially regulated both during the initial response to axotomy and the subsequent events of regeneration.

The increase in actin synthesis occurs earlier than the increase in overall tubulin synthesis, which is also shown by the initial shift in the tubulin/actin ratio (Table 1). This may reflect an earlier requirement for increased actin synthesis during regeneration, perhaps related to the involvement of actin in growth cone function (Yamada et al., 1970; for review, see Bunge, 1986). Although initial formation of growth cones presumably utilizes existing axonal actin, since it can occur without cell body involvement (Rotshenker, 1981), sustained regeneration may require an increase in actin synthesis. In the regenerating sciatic nerve, some actin is transported along axons at $>30 \mathrm{~mm} / \mathrm{d}$, so that newly synthesized actin reaches the growth cones of the axons by $2 \mathrm{~d}$ after axotomy (B. Reynolds and M. A. Bisby, unpublished observations). The involvement of increased actin synthesis in growth cone function is also suggested by the fact that the peak synthesis occurs within a few days after crush, the period of axonal sprout and growth cone formation; thereafter, it declines during the phase of axonal elongation before the majority of regenerating axons reached their targets between 11-14 $\mathrm{d}$. This interpretation is also supported by the observation that actin synthesis was higher after nerve resection when more sprouts are growing out as compared with nerve crush (Shawe, 1953).

Compared with actin, tubulin synthesis increases later and reaches a plateau that persists after arrival of the axons at their targets by $11-14 \mathrm{~d}$. This later, prolonged, increase in tubulin synthesis may reflect an increased demand for tubulin as the regenerating axons elongate and subsequently increase in diameter. The number of axonal microtubules increases with increasing fiber diameter (Friede and Samorajski, 1970).

The synthesis of neurofilament proteins drops within $24 \mathrm{hr}$ after axotomy in the facial motoneuron system. This is consistent with a recent report of Hoffman et al. (1987), who demonstrated an early decrease in mRNA for neurofilament 68 in the large dorsal root ganglion cells following axotomy (also Wong and Oblinger, 1987). There is also reduced neurofilament immunoreactivity in the proximal facial axons, which decrease in calibre (Fig. 3; see also Kreutzberg and Schubert, 1971). These findings are consistent with the hypothesis that neurofilaments are involved in the control of fiber diameter: Reduction in their synthesis and transport may account for the proximal axonal atrophy following axotomy (Hoffman et al., 1985, 1987).

\section{Decreased neurofilament synthesis contrasts with cell body neurofilament content}

The decrease in neurofilament synthesis contrasts with observations of neurofilament accumulation in axotomized cell bodies (Pannese, 1963; Zelena, 1971; Moss and Lewkowicz, 1983; Sinicropi and Mcllwain, 1983), though this is a variable phenomenon in different cell types (reviewed in Barron, 1983). In spite of the drastic reduction in neurofilament synthesis, we did not observe decreases in the immunoreactivity of the cell body (Fig. 3, $c, d, g$, and $h$ ). Since the perikarya of the facial motoneurons swell after axotomy (Tetzlaff and Kreutzberg, 1984), there might even be an increased cell body content of neurofilaments. After axotomy, phosphorylated neurofilament protein becomes detectable in dorsal root ganglion cell bodies (Bignami et al., 1986; Goldstein et al., 1987; Rosenfeld et al., 1987). Cell body neurofilament content is the net result of synthesis and axonal transport. It is possible that increased phosphorylation may reduce the proportion of neurofilaments committed to transport so that the cell body content remains relatively stable (or increases) despite reduced synthesis. Possibly the accumu- 

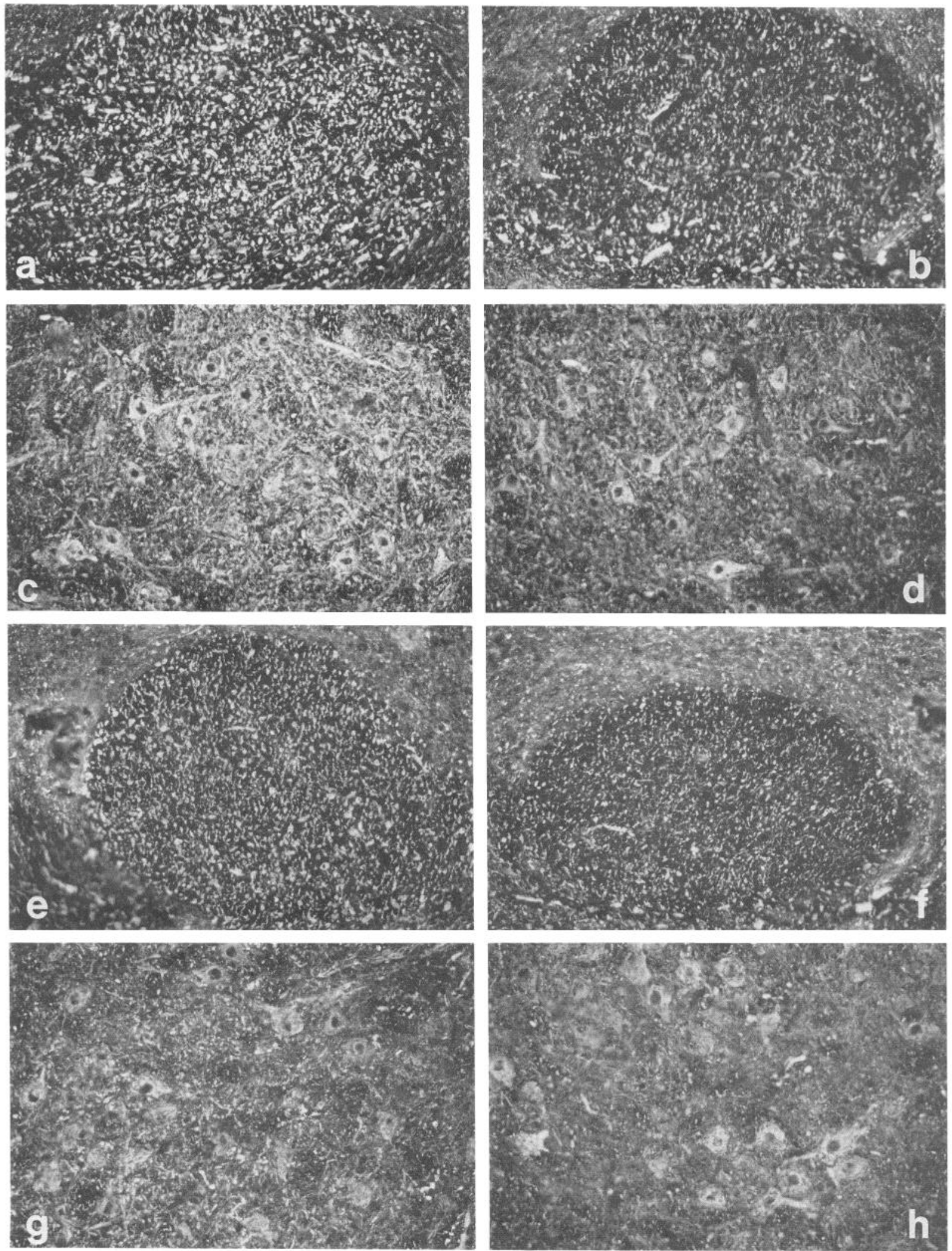

Figure 3. Immunostaining of the facial nuclei $(c, d, g$, and $h)$ and inner facial genu $(a, b, e$, and $f)$ using a monoclonal antibody to neurofilament 150 polypeptide, visualized by a secondary antibody coupled to fluorescein. $a$, Contralateral control; $b$, inner facial genu, $7 \mathrm{~d}$ postcrush; $c$, contralateral control; $d$, facial nucleus, $7 \mathrm{~d}$ postcrush; $e$, contralateral control; $f$, inner facial genu, $7 \mathrm{~d}$ postresection; $g$, contralateral control; $h$, facial nucleus, 7 d postresection. Note the decreased neurofilament immunoreactivity in the proximal facial axons at the inner facial genu. Here, the axons are cut transversely $1.5-2 \mathrm{~mm}$ distal to the cell bodies and about $10 \mathrm{~mm}$ proximal to the lesion. Note that immunoreactivity decreases in the neuropil of the axotomized facial motonuclei $(d, h)$ but shows no change in the perikarya of the axotomized motoneurons. $\times 200$. 


\begin{tabular}{|c|c|c|c|c|c|}
\hline Group & Tub/act & Tub/NF68 & Tub/NF150 & Act/NF68 & $N F 68 / 150$ \\
\hline \multicolumn{6}{|c|}{$12 \mathrm{hr}(n=2+2)$} \\
\hline Control & 5.45 & 5.08 & 5.23 & 0.98 & 1.01 \\
\hline $\mathrm{Cr} /$ res & 4.90 & 5.65 & $6.94^{a}$ & 1.19 & $1.19^{a}$ \\
\hline Mean diff. & -0.55 & +0.58 & +1.71 & +0.21 & +0.18 \\
\hline$\pm \mathrm{SEM}$ & 0.66 & 0.57 & 1.22 & 0.14 & 0.07 \\
\hline \multicolumn{6}{|l|}{$1 \mathrm{~d}(n=5)$} \\
\hline Control & 7.74 & 3.99 & 6.00 & 0.62 & 1.49 \\
\hline Resected & $5.52^{a}$ & $5.97^{a}$ & 7.80 & $1.31^{a}$ & 1.29 \\
\hline Mcan diff. & -2.22 & +1.98 & +1.81 & +0.69 & -0.20 \\
\hline \pm SEM & 1.23 & 0.43 & 0.83 & 0.16 & 0.09 \\
\hline \multicolumn{6}{|l|}{$3 \mathrm{~d}(n=4)$} \\
\hline Control & 4.43 & 3.86 & 5.55 & 0.93 & 1.45 \\
\hline Crushed & $3.53^{a}$ & $13.95^{a}$ & $18.66^{a}$ & $4.28^{a}$ & 1.32 \\
\hline Mean diff. & -0.90 & +10.09 & +13.11 & +3.35 & -0.13 \\
\hline \pm SEM & 0.27 & 1.27 & 5.05 & 0.82 & 0.31 \\
\hline \multicolumn{6}{|l|}{$7 \mathrm{~d}(n=5)$} \\
\hline Control & 4.63 & 4.76 & 6.47 & 1.03 & 1.38 \\
\hline Crushed & 4.97 & $17.60^{a, b}$ & $20.24^{a, b}$ & $3.58^{a, b}$ & 1.28 \\
\hline Mean diff. & +0.34 & +12.84 & +13.77 & +2.55 & -0.10 \\
\hline \pm SEM & 0.19 & 2.11 & 2.44 & 0.45 & 0.27 \\
\hline \multicolumn{6}{|l|}{$7 \mathrm{~d}(n=6)$} \\
\hline Control & 4.11 & 4.05 & 4.04 & 1.01 & 1.15 \\
\hline Resected & $3.20^{a}$ & $29.1^{a}$ & $41.63^{a}$ & $9.41^{a}$ & 1.45 \\
\hline Mean diff. & -0.91 & +25.05 & +37.59 & +8.40 & +0.30 \\
\hline \pm SEM & 0.34 & 2.80 & 7.18 & 1.00 & 0.25 \\
\hline \multicolumn{6}{|l|}{$14 \mathrm{~d}(n=5)$} \\
\hline Control & 5.96 & 4.15 & 6.64 & 0.70 & 1.55 \\
\hline Crushed & 6.29 & $8.84^{a}$ & $10.90^{a}$ & $1.59^{a}$ & $1.21^{a}$ \\
\hline Mean diff. & +0.33 & +4.69 & +4.26 & +0.89 & -0.34 \\
\hline \pm SEM & 1.28 & 0.85 & 0.61 & 0.27 & 0.08 \\
\hline \multicolumn{6}{|l|}{$21 \mathrm{~d}(n=4)$} \\
\hline Control & 9.36 & 4.87 & 4.21 & 0.53 & 0.89 \\
\hline Crushed & 9.74 & $5.50^{b}$ & $4.96^{b}$ & $0.62^{b}$ & 0.90 \\
\hline Mean diff. & +0.38 & +0.63 & +0.75 & +0.11 & +0.01 \\
\hline$\pm \mathrm{SEM}$ & 0.58 & 0.56 & 0.60 & 0.08 & 0.09 \\
\hline \multicolumn{6}{|l|}{$21 \mathrm{~d}(n=4)$} \\
\hline Control & 8.12 & 4.17 & 3.92 & 0.54 & 0.99 \\
\hline Resected & 9.84 & $18.50^{a}$ & $15.50^{a}$ & $2.16^{a}$ & 0.80 \\
\hline Mean diff. & +1.72 & +14.33 & +11.58 & +1.62 & -0.19 \\
\hline$\pm \mathrm{SEM}$ & 2.15 & 1.87 & 3.67 & 0.67 & 0.08 \\
\hline
\end{tabular}

Cr, crush; res, resection; diff., difference; Tub, tubulin; act, actin.

${ }^{a}$ Groups that were significantly different from the contralateral (control) group in a Wilcoxon signed-rank test for paired differences ( $p<0.062$ for $n=4$ and $p<0.05$ for $n=5$ or 6 , 1-tailed).

${ }^{b}$ Groups where the values from crush axotomy were significantly different from those with resection at the same postaxotomy interval in a 2 -tailed Wilcoxon-Mann-Whitney test $(p<0.05)$.

lation of phosphorylated neurofilaments in the cell body is involved in the suppression of neurofilament synthesis.

Differential regulation in successful and impaired regeneration Some parameters of the retrograde neuronal response to axotomy are dependent on successful regeneration, but others are not (see also Watson, 1968; Grafstein and McQuarrie, 1978; Benowitz et al., 1983; Kreutzberg et al., 1984; Redshaw and Bisby, 1984; Burmeister and Grafstein, 1985). Actin synthesis returned to normal irrespective of target contact. The increased tubulin synthesis remained elevated when regeneration was impaired. This dissociation of actin and tubulin synthesis emphasizes their differential regulation. Neurofilament synthesis re- mained decreased if reinnervation was prevented. While this appears consistent with the suggestion that neurofilament synthesis is controlled by retrograde trophic interaction with the target (Hoffman et al., 1987), we emphasize that recovery of neurofilament synthesis has begun $7 \mathrm{~d}$ after axotomy before the axons contact their targets (11-14 d), and we speculate that the trophic support may be provided by the Schwann cells encountered by the regenerating axons (Richardson and Ebendal, 1982; Heumann et al., 1987)

\section{Altered composition of the cytoskeleton}

The differential changes in the synthesis of cytoskeletal proteins may result in significant changes in their interactions in the axon. 
In intact axons, microtubules interact with neurofilaments (Ellisman and Porter, 1980; Shelanski et al., 1981; Tashiro et al., 1984; Meller, 1985), and the majority of the tubulin migrates at the same SCa velocity of axonal transport as the neurofilament proteins (Hoffman and Lasek, 1975; Oblinger et al., 1987). In regenerating axons, the decreased number of neurofilaments could result in fewer neurofilament-microtubule interactions, so that a greater proportion of tubulin would travel at a higher velocity. This is indeed the case since during regeneration a greater portion of the tubulin is transported at a higher velocity, i.e., in the $\mathrm{SCb}$ of axonal transport (Hoffman and Lasek, 1980; Hoffman et al., 1985). This proportion of tubulin traveling with $\mathrm{SCb}$ may be a determinant of axonal elongation (McQuarrie, 1983), and a correlation between SCb velocity and axonal regeneration rate has been reported (Wujek and Lasek, 1983). Thus, it is possible that changes in the tubulin/neurofilament ratio could determine the rate of axonal elongation. We found this ratio to be further increased, due to a further reduction in neurofilament synthesis, by a second lesion which increases the regeneration rate by $40 \%$ (Tetzlaff et al., 1987).

\section{References}

Aldskogius, H., K. D. Barron, and R. Regal (1980) Axon reaction in dorsal motor vagal and hypoglossal neurons of the adult rat. Light microscopy and RNA-cytochemistry. J. Comp. Neurol. 193: 165177.

Aldskogius, H., K. D. Barron, and R. Regal (1984) Axon reaction in hypoglossal and dorsal motor vagal neurons of adult rat. Incorporation of [3H]-leucine. Exp. Neurol. 85: 139-151.

Austin, L. (1985) Molecular aspects of nerve regeneration. In Alterations of Metabolites in the Nervous System, Handbook of Neurochemistry, 2nd ed., Vol. 9, A. Lajtha, ed., pp. 1-45, Plenum, New York

Bamburg, J. R., D. Bray, and K. Chapman (1986) Assembly of microtubules at the tip of growing axons. Nature 321: 788-790.

Barron, K. D. (1983) Comparative observations on the cytologic reactions of central and peripheral nerve cells to axotomy. In Spinal Cord Reconstruction, C. C. Kao, R. P. Bunge, and P. J. Reier, eds. pp. 7-40, Raven, New York.

Benowitz, L. I., M. G. Yoon, and E. R. Lewis (1983) Transported proteins in the regenerating optic nerve: Regulation by interactions with the optic tectum. Science 222: 185-188.

Bignami, A., N. H. Chi, and D. Dahl (1986) Neurofilament phosphorylation in peripheral nerve regeneration. Brain Res. 375: 73-82.

Black, M. M., P. Keyser, and E. Sobel (1986) Interval between the synthesis and assembly of cytoskeletal proteins in cultured neurons. J. Neurosci. 6: 1004-1012.

Bonner, W. M., and R. A. Laskey (1974) A film detection method for tritium-labeled proteins and nucleic acids in polyacrylamide gels. Eur. J. Biochem. 46: 83-88.

Brattgård, S. O., H. Hydén, and J. Sjöstrand (1958) Incorporation of orotic acid-14C and lysine-14C in regenerating single nerve cells. Nature 182: 801-802.

Bunge, M. B. (1986) The axonal cytoskeleton: Its role in generating and maintaining cell form. Trends Neurosci. 9: 477-482.

Burmeister, D. W., and B. Grafstein (1985) Removal of optic tectum prolongs the cell body reaction to axotomy in goldfish retinal ganglion cells. Brain Res. 327: 45-51.

Burrell, H. R., A. M. Heacock, R. D. Water, and B. W. Agranoff (1979) Increased tubulin messenger RNA in the goldfish retina during optic nerve regeneration. Brain Res. 168: 628-632.

Edström, J.-E. (1959) Ribonucleic acid changes in the motoneurons of the frog during axon regeneration. J. Neurochem. 5: 43-49.

Ellisman, M. H., and K. R. Porter (1980) Microtrabecular structure of the axoplasmic matrix: Visualization of cross-linking structures and their distribution. J. Cell Biol. 87: 464-479.

Engh, C. A., B. H. Schofield, S. B. Doby, and R. A. Robinson (1971) Perikaryal synthetic function following reversible and irreversible peripheral axon injuries as shown by radioautography. J. Comp. Neurol. 142: $465-480$
Friede, R. L., and T. Samorajski (1970) Axon caliber related to neurofilaments and microtubules in sciatic nerve fibers of rats and mice. Anat. Rec. 167: 379-388.

Giulian, D., H. Des Ruisseaux, and D. Cowburn (1980) Biosynthesis and intra-axonal transport of proteins during neuronal regeneration. J. Biol. Chem. 255: 6494-6501.

Goldstein, M. E., H. S. Cooper, J. Bruce, M. J. Carden, V. M.-Y. Lee, and W. W. Schlaepfer (1987) Phosphorylation of neurofilament proteins and chromatolysis following transection of rat sciatic nerve. J. Neurosci. 7: 1586-1594.

Graeber, M. B., and G. W. Kreutzberg (1986) Astrocytes increase in glial fibrillary acidic protein during retrograde changes of facial motor neurons. J. Neurocytol. 15: 363-373.

Grafstein, B., and I. G. McQuarrie (1978) The role of the nerve cell body in axonal regeneration. In Neuronal Plasticity, C. W. Cotman, ed., pp. 155-195, Raven, New York.

Hall, M. E. (1982) Changes in synthesis of specific proteins in axotomized dorsal root ganglia. Exp. Neurol. 76: 83-93.

Hall, M. E., D. L. Wilson, and G. C. Stone (1978) Changes in synthesis of specific proteins following axotomy: Detection with two-dimensional gel electrophoresis. J. Neurobiol. 9: 353-366.

Heacock, A. M., and B. W. Agranoff (1976) Enhanced labeling of a retinal protein during regeneration of optic nerve in goldfish. Proc. Natl. Acad. Sci. USA 73: 828-832.

Heumann, R., S. Korsching, C. Bandtlow, and H. Thoenen (1987) Changes of nerve growth factor synthesis in nonneuronal cells in response to sciatic nerve transection. J. Cell Biol. 104: 1623-1631.

Hoffman, P. N., and R. J. Lasek (1975) The slow component of axonal transport: Identification of major structural polypeptides of the axon and their generality among mammalian neurons. J. Cell Biol. 66: $351-366$

Hoffman, P. N., and R. J. Lasek (1980) Axonal transport of the cytoskeleton in regenerating motor neurons: Constancy and change. Brain Res. 202: 317-333.

Hoffman, P. N., G. W. Thompson, J. W. Griffin, and D. L. Price (1985) Changes in neurofilament transport coincide temporally with alterations in the caliber of axons in regenerating motor fibers. J. Cell Biol. 101: $1332-1340$.

Hoffman, P. N., D. W. Cleveland, J. W. Griffin, P. W. Landes, N. J. Cowan, and D. L. Price (1987) Neurofilament gene expression: A major determinant of axonal caliber. Proc. Natl. Acad. Sci. USA 84: 3472-3476.

Julien, J.-P., and W. E. Mushynski (1982) Multiple phosphorylation sites in mammalian neurofilament polypeptides. J. Biol. Chem. 257: 10467-10470.

Kreutzberg, G. W. (1982) Acute neuronal reaction to injury. In Repair and Regeneration of the Nervous System, J. G. Nicholls, ed., pp. 5769 , Springer, Berlin.

Kreutzberg, G. W., and P. Schubert (1971) Volume changes in axons during regeneration. Acta Neuropathol. (Berl.) 17: 220-226.

Kreutzberg, G. W., W. Tetzlaff, and L. Toth (1984) Cytochemical changes of cholinesterase in motor neurons during regeneration. In Cholinesterases-Fundamental and Applied Aspects, M. Brzin, T. Kiauta, and E. A. Barnard, eds., pp. 273-288, de Gruyter, Berlin.

Lasek, R. J. (1986) Polymer sliding in axons. J. Cell Sci. Suppl. 5: 161-179.

Lasek, R. J., and M. J. Katz (1987) Mechanisms at the axon tip regulate metabolic processes critical to axonal elongation. Prog. Brain Res. 71: 49-60.

Lieberman, A. R. (1971) The axon reaction: A review of the principal features of perikaryal responses to axon injury. Int. Rev. Neurobiol. 14: $49-124$.

Mariash, C. N., S. Seelig, and J. H. Oppenheimer (1982) A rapid, inexpensive, quantitative technique for the andysis of two-dimensional electrophoretograms. Anal. Biochem. 121: 388-394.

McLoon, L. K., and A. LaVelle (1981) Tritiated leucine incorporation in the developing hamster facial nucleus with injury: An autoradiographic study. Exp. Neurol. 74: 573-586.

McQuarrie, I. G. (1983) Role of the cytoskeleton in the regenerating nervous system. In Nerve, Organ and Tissue Regeneration, F. J. Seil, ed., pp. 51-88, Academic, New York and London.

Meller, K. (1985) Ultrastructural aspects of cryofixed nerves. Cell Tissue Res. 242: 289-300.

Moss, T. H., and S. J. Lewkowicz (1983) The axon reaction in motor 
and sensory neurones of mice studied by a monoclonal antibody marker of neurofilament protein. J. Neurol. Sci. 60: 267-280.

Neumann, D., T. Scherson, I. Ginzburg, U. Z. Littauer, and M. Schwartz (1983) Regulation of mRNA levels for microtubule proteins during nerve regeneration. FEBS Lett. 162: 270-276.

Nixon, R. A., and K. B. Logvinenko (1986) Multiple fates of newly synthesized neurofilament proteins: Evidence for a stationary neurofilament network distributed nonuniformly along axons of retinal ganglion cell neurons. J. Cell Biol. 102: 647-659.

Oblinger, M. M., S. T. Brady, I. G. McQuarrie, and R. J. Lasek (1987) Cytotypic differences in the protein composition of the axonally transported cytoskeleton in mammalian neurons. J. Neurosci. 7: 453-462.

O'Farrell, P. (1975) High resolution two-dimensional electrophoresis of proteins. J. Biol. Chem. 250:4007-4021.

Pannese, E. (1963) Investigations on the ultrastructural changes of the spinal ganglion neurons in the course of axon regeneration and cell hypertrophy. Z. Zellforsch. 61: 561-586.

Quesada, M. H., D. B. Millar, and R. Smejkal (1986) Tubulin synthesis in the regenerating rat superior cervical ganglion: A biphasic response. J. Neurobiol. 17: 77-82.

Redshaw J. D., and M. A. Bisby (1985) Comparison of the effects of sciatic nerve crush or resection on the proteins of fast axonal transport in rat dorsal root ganglion cell axons. Exp. Neurol. 88: 437-446.

Richardson, P. M., and T. Ebendal (1982) Nerve growth activities in rat peripheral nerve. Brain Res. 246: 57-64.

Rosenfeld, J., M. E. Dorman, J. W. Griffin, L. A. Sternberger, N. H. Sternberger, and D. L. Price (1987) Distribution of neurofilament antigens after axonal injury. J. Neuropathol. Exp. Neurol. 46: 269282.

Rotschenker, S. (1981) Sprouting and synapse formation by motor axons separated from their cell bodies. Brain Res. 223: 141-145.

Shawe, G. D. H. (1955) On the number of branches formed by regenerating nerve-fibres. Br. J. Surg. 42: 474-488.

Shelanski, M. L., J.-F. Leterrier, and R. K. H. Liem (1981) Evidence for interactions between neurofilaments and microtubules. Neurosci. Res. Prog. Bull. 19: 32-43.

Singer, P., and S. Mehler (1986) Glucose and leucine uptake in the hypoglossal nucleus after hypoglossal nerve transection with and without prevented regeneration in the Sprague-Dawley rat. Neurosci. Lett. 67: 73-77.
Sinicropi, D. V., and D. L. Mcllwain (1983) Changes in the amounts of cytoskeletal proteins within the perikarya and axons of regenerating frog motoneurons. J. Cell Biol. 96: 240-247.

Smith, C. B., A. M. Crane, M. Kadekaro, B. W. Agranoff, and L. Sokoloff (1984) Stimulation of protein synthesis and glucose utilization in the hypoglossal nucleus induced by axotomy. J. Neurosci. 4: 2489-2496.

Tashiro, T., M. Kurokawa, and Y. Komiya (1984) Two populations of axonally transported tubulin differentiated by their interactions with neurofilaments. J. Neurochem. 43: 1220-1225.

Tetzlaff, W., and G. W. Kreutzberg (1984) Enzyme changes in the rat facial nucleus following a conditioning lesion. Exp. Neurol. 85: 547564.

Tetzlaff, W., M. A. Bisby, and G. W. Kreutzberg (1986a) Protein changes in the axotomized facial and hypoglossal nucleus of the rat. Soc. Neurosci. Abstr. 12: 277.

Tetzlaff, W., M. B. Graeber, and G. W. Kreutzberg (1986b) Reaction of motoneurons and their microenvironment to axotomy. Exp. Brain Res. Suppl. 13: 3-8.

Tetzlaff, W., M. A. Bisby, C. A. Krekoski, and I. M. Parhard (1987) A conditioning lesion does not further stimulate tubulin and actin synthesis but further decreases neurofilament synthesis in the facial nucleus of the rat. Soc. Neurosci. Abstr. 13: 291.

Tetzlaff, W., M. B. Graeber, M. A. Bisby, and G. W. Kreutzberg (1988) Increased glial fibrillary acidic protein synthesis in astrocytes during retrograde reaction of the axotomized rat facial nucleus. Glia 1: $90-$ 95.

Watson, W. E. (1968) Observations on the nucleolar and total cell body nucleic acid of injured nerve cells. J. Physiol. (Lond.) 196:655676.

Wong, J., and M. M. Oblinger (1987) Changes in neurofilament gene expression occur after axotomy of dorsal root ganglion neurons: An in situ hybridization study. Metabol. Brain Dis. 2: 291-303.

Wujek, J. R., and R. J. Lasek (1983) Correlation of axonal regeneration and slow flow component $b$ in two branches of a single axon. $J$ Neurosci. 3: 243-251.

Yamada, K. M., B. S. Spooner, and N. K. Wessells (1970) Axon growth: Roles of microfilaments and microtubules. Proc. Natl. Acad. Sci. USA 66: 1206-1212.

Zelena, J. (1971) Neurofilaments and microtubules in sensory neurons after peripheral nerve section. Z. Zellforsch. 117: 191-211. 